\title{
POLÍTICA PÚBLICA CARCERÁRIA: UMA INSTITUCIONALIZADA VIOLAÇÃO DE DIREITOS FUNDAMENTAIS IMPULSIONADA PELA CRIMINALIZAÇÃO DAS DROGAS
}

\section{PRISON PUBLIC POLICY: AN INSTITUTIONAL VIOLATION OF FUNDAMENTAL RIGHTS OF DRUGS DRIVEN BY CRIMINALIZATION}

\begin{abstract}
MARCO AURÉLIO SOUZA DA SILVA
Mestre em Direito pela Universidade Federal de Santa Catarina (UFSC), Especialização em Direito Penal e Processo Penal pela Universidade do Vale do Itajaí (UNIVALI), Auditor Fiscal de Controle Externo do Tribunal de Contas do

Estado de Santa Catarina.

marcoaurelio_vet@yahoo.com.br
\end{abstract}

\begin{abstract}
RESUMO
Consideradas verdadeiras masmorras medievais, as prisões têm servido para depósito de seres humanos que vivem em degradantes condições, violadoras de direitos fundamentais, que vão além da pena imposta pelos delitos cometidos. O problema da caótica situação carcerária brasileira é impulsionado diariamente pelo aprisionamento em massa e pelo controle social decorrente da política pública de repressão às drogas ilícitas. Cotejando o marco teórico da Criminologia crítica com os direitos fundamentais positivados na Constituição Federal de 1988, em seu núcleo dignidade humana, e empregando o método dedutivo, o estudo tem por objetivo evidenciar a institucionalizada violação de direitos fundamentais pela política pública carcerária, por meio de um controle social incidente de modo seletivo sobre os indivíduos pertencentes às classes desfavorecidas ou vulneráveis. A conclusão da pesquisa é a de que não há como negar a omissão do Estado e a conivência das instituições públicas fiscalizadoras na situação que envolve o sistema carcerário, ante as revelações de violação de diversos direitos fundamentais, como tortura, fome, maus-tratos, superlotação, abusos sexuais, morte, entre outros, como forma de controle social das classes vulneráveis.
\end{abstract}

Palavras-chave: controle social; criminologia; direitos fundamentais; drogas; sistema penal.

\begin{abstract}
Considered true medieval dungeons, prisons have served to deposit humans living in degrading conditions, violating the fundamental rights that go beyond the sentence imposed for crimes committed. The problem of chaotic Brazilian prison situation is driven daily by mass imprisonment and the social control of public policy resulting crackdown on illicit drugs. Comparing the theoretical framework of Critical Criminology with fundamental rights in the Constitution of 1988, at its core human dignity, and employing the deductive method, the study aims to highlight the institutionalized violation of fundamental rights by prison policy through social control incident selectively on individuals belonging to disadvantaged or vulnerable classes. The conclusion of the research is that there is no denying the failure of the state and the connivance of supervisory public institutions in the situation surrounding the prison system, compared to the revelations in violation of different fundamental rights, such as torture, starvation, mistreatment, overcrowding, sexual abuse, death, among others, as a form of social control of vulnerable classes.
\end{abstract}

Keywords: social control; criminology; drugs; fundamental rights; penal system. 


\section{SUMÁRIO}

INTRODUÇÃO; 1. A CRIMINALIDADE E O SISTEMA PENAL EM UMA ABORDAGEM CRIMINOLÓGICA; 2. DROGAS: UMA POLÍTICA DE SUCESSO, FRACASSO E CONTRADIÇÃO; 3. POLÍTICA PÚBLICA DE ENCARCERAMENTO EM MASSA E CONTROLE SOCIAL; 4.0 SISTEMA CARCERÁRIO E A INSTITUCIONALIZADA VIOLAÇÃO DE DIREITOS FUNDAMENTAIS; CONCLUSÃO; REFERÊNCIAS.

\section{INTRODUÇÃO}

Superlotação, tortura, maus-tratos, abusos sexuais e morte estão entre as principais condições oferecidas pelo sistema carcerário. Não é de hoje que a imprensa e os estudos acadêmicos denunciam o caótico quadro de violação aos direitos fundamentais a que estão submetidos os encarcerados e todos aqueles que se encontram direta ou indiretamente ligados ao sistema (servidores, famílias etc.).

A situação absurda tem sido o resultado da ausência de política pública e da omissão do Estado quanto ao oferecimento de condições mínimas de segurança, dignidade, preservação da integridade física, proteção da vida, promoção da saúde, do trabalho e da educação. Esse problema é impulsionado pelo encarceramento em massa, pela violência e pelo controle social decorrente da política pública beligerante contra as drogas.

Em um Estado Constitucional e Democrático de Direito, a observação dos direitos fundamentais constitui um dever dos agentes públicos e das instituições fiscalizadoras, que também têm contribuído significativamente com a omissão, o descaso e a ineficiência de suas atuações.

Se, de um lado, sobra omissão, de outro, sobra também incremento punitivo relacionado à repressão às drogas consideradas ilícitas. Em uma perspectiva histórica, observa-se que a questão das drogas sofre uma intensa influência de políticas internacionais, com elaboração de convenções proibitivas, postulados de segurança nacional e enorme investimento de recursos na área militar, disseminando a ideia de guerra que molda a política criminal repressiva e agrava a situação carcerária.

É nessa conjuntura que se sobressai o controle social antidrogas, sob o manto de um sistema penal que prega o discurso de segurança pública dirigido à construção de mais presídios, produção de leis penais mais rigorosas, maior vigilância eletrônica, aumento do número de 
policiais e encarceramento em massa, abrindo o espaço para uma política de violação dos direitos fundamentais, notadamente contra as classes sociais desfavorecidas ou vulneráveis, composta essencialmente por jovens, pobres, negros, moradores da periferia.

A partir de apontamentos acerca do sistema penal, do discurso criminológico crítico e do encarceramento em massa impulsionado pela criminalização das drogas, o estudo tem por objetivo abordar o controle social exercido pela política pública do sistema carcerário, visando demonstrar a institucionalizada violação de direitos fundamentais.

Para o desenvolvimento do presente trabalho, adota-se o marco teórico da Criminologia crítica, cotejando-o com os direitos fundamentais positivados na Constituição Federal de 1988, cujo núcleo é a dignidade da pessoa humana. Como metodologia, emprega-se o método dedutivo a partir de pesquisa bibliográfica e documental, confrontando-se suportes doutrinários e dados estatísticos referentes à população carcerária nacional.

A relevância da discussão teórica permite uma aproximação empírica e analítica de um problema que se propaga no País e que produz um verdadeiro extermínio de pessoas.

0 estudo é estruturado inicialmente com uma abordagem criminológica acerca da criminalidade e do sistema penal. Após, analisa-se a política repressiva antidrogas e o encarceramento em massa como forma de controle social. E, por fim, são tecidas considerações acerca da situação do sistema carcerário e a institucionalizada violação de direitos fundamentais.

\section{A CRIMINALIDADE E O SISTEMA PENAL EM UMA ABORDAGEM CRIMINOLÓGICA}

Definido por Zaffaroni como um "controle social punitivo institucionalizado", o sistema penal compreende atividades que vão desde as do legislador, passando pelas dos policiais, juízes, promotores, funcionários, até as de execução penal, convergindo na institucionalização do sistema. Na percepção do penalista, o sistema penal abarca desde a suspeita da prática de um delito até a imposição ou execução de uma pena, pressupondo uma atividade normativa criadora da lei que institucionaliza o procedimento, a atuação dos funcionários e define os casos e as condições para essa atuação. ${ }^{1}$

${ }^{1}$ ZAFFARONI, Eugenio Raúl; PIERANGELI, José Henrique. Manual de direito penal brasileiro: parte geral. 3. ed. rev. e atual. São Paulo: Revista dos Tribunais, 2001, p. 70. 
0 discurso de obediência aos princípios da legalidade, da legitimidade, da retribuição, da prevenção, do interesse público, da igualdade, da culpabilidade, da proteção de bens jurídicos e de combate à criminalidade, sustentado pelos defensores do sistema penal há várias décadas tem sido objeto de críticas no âmbito de pesquisas criminológicas, colocando frente a frente basicamente os enfoques da Criminologia positivista e da Criminologia crítica.

Para os teóricos da Criminologia tradicional positivista, esta é concebida como a ciência das causas da criminalidade, assentada sobre o paradigma etiológico, como premissa pré-constituída às definições (visão ontológica da criminalidade), não permitindo espaço para quaisquer questionamentos acerca das normas jurídicas e do papel das instituições oficiais na definição de comportamentos considerados criminosos ou desviantes.

Para essa corrente de pensamento, a criminalidade é definida como um status atribuído a certos indivíduos, cuja propensão a delinquir pode ser determinada por suas características biológicas, psicológicas ou fatores socioambientais a que estão submetidos e que os diferenciam de outros na sociedade. ${ }^{2}$

Por ser considerada uma entidade ontológica, na visão positivista, a criminalidade procura ser justificada como necessidade de um saber ou uma ciência das causas para a investigação das condutas desviantes, a fim de individualizar as medidas adequadas para conter ou eliminar os indivíduos selecionados. A necessidade desse saber causal, na visão de Andrade, origina como consequência um saber tecnológico, dogmático, representado pelo diagnóstico da patologia criminal (doença) e pelo tratamento que leva à cura (remédio). ${ }^{3}$

E é com base no saber causal que nasce o discurso maniqueísta do bem e do mal, ou seja, de combate à criminalidade (o "mal") em defesa da sociedade (o "bem"), respaldado pela ciência, de maneira que as supostas causas da criminalidade dão sustentação a uma luta científica contra o crime e a uma política criminal de encarceramento em massa.

Contudo, os argumentos teóricos da Criminologia tradicional não ficaram imunes a críticas, porquanto a concepção etiológica do delito e ontológica do criminoso é desconstituída

\footnotetext{
${ }^{2} \mathrm{Na}$ lição de Baratta, a Criminologia positivista se baseia na teoria patológica da criminalidade, considerando as características biológicas e psicológicas que diferenciam os indivíduos "criminosos" dos indivíduos "normais". Assim, seu objeto não é propriamente o delito, como conceito jurídico, mas o homem delinquente, como um indivíduo diferente, de maneira que esse modelo estuda as causas ou os fatores da criminalidade (paradigma etiológico) a fim de individualizar as medidas para combatê-los, intervindo no sujeito criminoso (correcionalismo) (BARATTA, Alessandro. Criminologia crítica e crítica do direito penal: introdução à sociologia do direito penal. 2. ed. Rio de Janeiro: Freitas Bastos, 1999, p. 29). ${ }^{3}$ ANDRADE, Vera Regina Pereira de. Sistema penal máximo x cidadania mínima: Códigos da violência na era da globalização. Porto Alegre: Livraria do Advogado, 2003, p. 38.
} 
pela Criminologia crítica, que concebe a criminalidade, o crime e o criminoso como uma construção efetuada pelas agências de controle social, a partir da rotulação ou etiquetamento de determinados indivíduos como desviantes. Conforme assinala Andrade, passa-se de uma ciência das causas da criminalidade (paradigma etiológico) para uma ciência das condições de criminalização (paradigma da reação social), ocupando-se do controle sociopenal e da análise da estrutura, operacionalidade e reais funções do sistema penal. ${ }^{4}$

A Criminologia crítica estabelece, portanto, um olhar crítico frente ao sistema penal como um todo (incluído aqui a prisão), analisando suas funções e as soluções de que lança mão a fim de evitar e controlar os conflitos sociais. Nessa mudança do enfoque do criminoso para as condições estruturais e institucionais do desvio ganham destaques as análises críticas acerca da "criminalidade de colarinho branco" ${ }^{5}$, das "cifras negras da criminalidade"6 e das estatísticas criminais $^{7}$, nas quais se fundamenta a Criminologia da reação social, importantes ao processo de descaracterização da concepção de criminalidade presente no senso comum e que revelam o caráter seletivo do sistema penal. $^{8}$

De acordo com a Criminologia crítica, os comportamentos lesivos aos bens jurídicos tutelados sofrem tratamentos desiguais, porquanto ocorre a criminalização e seleção de comportamentos característicos das classes inferiores ou desfavorecidas (relacionados à desocupação, subocupação, baixo grau de instrução educacional, entre outros) e a imunização de condutas lesivas praticadas pelas classes superiores ou favorecidas, no âmbito do modo de produção capitalista. ${ }^{9}$

\footnotetext{
${ }^{4}$ ANDRADE, Vera Regina Pereira de. A ilusão de segurança jurídica: do controle da violência à violência do controle penal. 2. ed. Porto Alegre: Livraria/Editora do Advogado, 2003, p. 183-184.

${ }^{5} \mathrm{Na}$ sociedade capitalista, evidencia-se a escassa perseguição da criminalidade de colarinho branco pelas malhas da lei, em razão do prestígio dos autores das infrações, a ausência de estereótipo que oriente as agências oficiais e o baixo poder estigmatizante das sanções aplicadas, ao contrário do que ocorre com a perseguição das infrações praticadas pelos estratos socialmente desfavorecidos.

${ }^{6}$ A cifra negra corresponde à diferença existente entre a criminalidade real (quantidade de delitos cometidos num tempo e lugar determinados) e a criminalidade aparente (criminalidade conhecida pelos órgãos de controle).

7 As estatísticas criminais, baseadas na criminalidade identificada e perseguida, mostram que a criminalidade de colarinho branco é bastante inferior, sugerindo um quadro falso da distribuição da criminalidade nos diversos estratos sociais.

${ }^{8}$ ANDRADE, Vera Regina Pereira de. Sistema penal máximo x cidadania mínima. Porto Alegre: Livraria do Advogado, 2003, p. 50.

${ }^{9}$ Baratta salienta que as normas do direito penal são aplicadas de maneira seletiva, refletindo as relações de desigualdade existentes e exercendo uma função de reprodução de tais relações. Desse modo, as sanções penais seletivas e estigmatizantes mantêm a escala vertical da sociedade e exercem uma função simbólica, na qual a punição de certos comportamentos ilegais serve para encobrir um número maior de comportamentos ilegais, que permanecem imunes ao processo de criminalização (BARATTA, Alessandro.
} 
A violência atribuída a esses comportamentos lesivos, logo, passa a ser identificada com a violência individual (de uma minoria), que se encontra, por sua vez, no centro do campo dogmático de crime, imunizando a relação entre a criminalidade e a violência institucional e estrutural. ${ }^{10}$ Daí a pertinência da crítica criminológica, ao afirmar a existência de uma lógica de relações desiguais na distribuição de recursos e de poder na sociedade, em que convivem, lado a lado, inúmeros comportamentos considerados proibidos - e sancionados - e diversos outros semelhantes permitidos - ou ignorados, a exemplo da prática do crime de falsidade ideológica de juízes que, diariamente, subscrevem declarações como prestadas em sua presença, nas quais jamais estiveram presentes, a conduta de não devolver livro emprestado, a prática de levar toalha de um hotel, a apropriação de objeto perdido etc., conforme lecionam Zaffaroni e Pierangeli. ${ }^{11}$

A criminalidade, desse modo, representa uma conduta majoritária e presente em todos os estratos sociais. Como enfatiza Andrade, "o que ocorre é que a criminalização é, com regularidade, desigual ou seletivamente distribuída pelo sistema penal”, de maneira que "os pobres não têm uma maior tendência a delinquir, mas sim a serem criminalizados”12. Destarte, as maiores chances de um indivíduo ser selecionado para integrar a denominada "população criminosa" estão concentradas nos níveis mais baixos da escala social, evidenciando a existência de um componente ideológico e de controle.

Percebe-se, então, que o componente ideológico é inerente à estrutura e à forma de funcionamento do sistema penal, do mesmo modo como este é inerente à estrutura e ao funcionamento do direito abstrato. Na lição de Baratta, a forma da mediação jurídica das relações de produção e das relações sociais na sociedade capitalista moderna é ideológica, na medida em que "o funcionamento do direito não serve, com efeito, para produzir a igualdade,

Criminologia crítica e crítica do direito penal: introdução à sociologia do direito penal. 2. ed. Rio de Janeiro: Freitas Bastos, 1999, p. 166).

${ }^{10}$ A violência corresponde a uma forma geral, envolvendo diversas outras específicas (violência individual, violência de grupo, violência institucional, violência internacional). Na violência individual, o agente é um indivíduo; na violência de grupo, o agente é um grupo social que se serve de indivíduos (ex: grupos paramilitares); na violência institucional, o agente é um órgão do Estado, um governo, o exército ou a polícia (ex: terrorismo de Estado, ditadura); na violência internacional, o agente é a administração de um Estado, que se dirige com suas ações contra o governo e o povo de outro Estado (ex: crimes internacionais) (BARATTA, Alessandro. Direitos Humanos: entre a violência estrutural e a violência penal. Fascículos de Ciências Penais, Porto Alegre: Sérgio Fabris, ano 6, v. 6, n. 2, abr./jun. 1993, p. 46-47).

${ }^{11}$ ZAFFARONI, Eugenio Raúl; PIERANGELI, José Henrique. Manual de direito penal brasileiro: parte geral. 3. ed., rev. e atual. São Paulo: Revista dos Tribunais, 2001, p. 58.

${ }^{12}$ ANDRADE, Vera Regina Pereira de. A ilusão de segurança jurídica: do controle da violência à violência do controle penal. 2 ed. Porto Alegre: Livraria/Editora do Advogado, 2003, p. 265. 
mas para reproduzir e manter a desigualdade", isso porque o direito penal não defende somente os bens essenciais a todos os cidadãos (e quando pune as ofensas aos bens essenciais o faz com intensidade desigual e de modo fragmentário), a lei penal não é igual para todos (já que o status de criminoso é distribuído de modo desigual entre os indivíduos), assim como o grau efetivo de tutela e a distribuição do status de criminoso são independentes da danosidade social das ações e da gravidade das infrações à lei. ${ }^{13}$

Transportando-se tais apontamentos criminológicos acerca do sistema penal e da concepção de criminalidade para o campo da criminalização das drogas ilícitas, conforme a seguir, constata-se a similaridade do processo de seleção de indivíduos (no caso, usuários e traficantes), rotulados como criminosos e escolhidos dentre aqueles de classes economicamente vulneráveis, e que alimentam as estatísticas de criminalidade e encarceramento.

\section{DROGAS: UMA POLÍTICA DE SUCESSO, FRACASSO E CONTRADIÇÃO}

A utilização de drogas ${ }^{14}$ modificadoras do estado de consciência, seja para consumo, comércio, efeitos religiosos, místicos, medicinais ou para simples fuga da realidade, acompanha gerações na história da humanidade. Contudo, nas últimas décadas, a questão das drogas tornadas ilícitas tem sido um tema tormentoso, sobretudo quando relacionado ao sistema punitivo.

Discutir a questão das drogas exige, antes de qualquer coisa, trazer à tona a origem de seu processo de criminalização para, posteriormente, afirmar as consequências da política proibicionista.

No campo internacional, verifica-se que após o fim da Segunda Guerra Mundial e a criação das Nações Unidas (1945), iniciaram-se as diretrizes de controle mundial antidrogas a

\footnotetext{
${ }^{13}$ BARATTA, Alessandro. Criminologia crítica e crítica do direito penal: introdução à Sociologia do Direito Penal. 2 ed. Rio de Janeiro: Freitas Bastos: Instituto Carioca de Criminologia, 1999, p. 162 e 213.

${ }^{14}$ Segundo a Organização Mundial de Saúde (OMS), a palavra "droga" significa "toda substância que, introduzida em um organismo vivo, pode modificar uma ou mais funções deste". Trata-se de um conceito amplo que abarca não apenas medicamentos destinados ao tratamento de enfermidades, como também outras substâncias ativas do ponto de vista farmacológico. Portanto, a palavra "droga" inclui substâncias diversas quanto à capacidade de produzir alterações físicas e/ou psíquicas, tendo em comum apenas a proibição. Ocorre que a proliferação indiscriminada do termo na mídia gerou uma distorção de seu significado, colaborando para que "droga" fosse assimilada de forma preconceituosa e associada ao proibido, na medida em que, como diz Olmo, a própria palavra funciona como estereótipo, mais do que como conceito, e como crença, mais do que como descoberta científica pesquisada, sendo "o bode expiatório por excelência" (OLMO, Rosa Del. A face oculta da droga. Trad. Tereza Ottoni. Rio de Janeiro: Revan, 1990, p. 21-22).
} 
partir da elaboração de três convenções: a Convenção Única sobre Entorpecentes $(1961)^{15}$, a Convenção sobre Substâncias Psicotrópicas $(1971)^{16}$ e a Convenção das Nações Unidas contra o Tráfico llícito de Entorpecentes e Substâncias Psicotrópicas, conhecida também como Convenção de Viena (1988) ${ }^{17}$.

Esse sistema classificatório de substâncias consubstancia-se em um modelo uniforme de controle que submete as substâncias proibidas a um regime internacional de interdição e que defende a criminalização do uso e do comércio com opção preferencial pela pena privativa de liberdade. Diante disso, torna-se importante registrar o contexto histórico de surgimento de tais legislações.

No período da Guerra Fria ocorre o investimento de uma enorme soma de recursos na área militar, alavancando o capitalismo industrial de guerra no campo geopolítico das relações internacionais, momento em que o combate às drogas ocupa um lugar de destaque como elemento de subversão associado à estratégia comunista. Surge, assim, um discurso em relação às drogas, coerente com os fins perseguidos, definido por Olmo como "discurso político-jurídico transnacional”, que corresponde ao surgimento do modelo geopolítico e à incorporação dos postulados da Doutrina da Segurança Nacional ao tema das drogas. ${ }^{18}$

Embora os principais objetivos da "guerra contra as drogas" estejam relacionados à erradicação dos cultivos, ao confisco das drogas, à destruição dos negócios de lavagem de dinheiro dentro dos Estados Unidos e ao castigo dos traficantes e consumidores, Olmo salienta que os maiores esforços são dirigidos aos dois primeiros porque "o mais importante dessa guerra é reduzir a quantidade de drogas que entra nos Estados Unidos e aumentar, em consequência,

\footnotetext{
${ }^{15}$ A Convenção Única sobre Entorpecentes, de 1961, instituiu um sistema internacional de controle sobre a produção, a distribuição e o comércio de drogas, atribuindo aos Estados signatários a responsabilidade pela incorporação dessas medidas às suas legislações nacionais. Nessa convenção, ficou estabelecido o prazo de 15 (quinze) anos para a eliminação gradual do ópio e de 25 (vinte e cinco) anos para a cocaína e a cannabis.

${ }^{16}$ Em 1971 as Nações Unidas elaboraram a Convenção sobre Substâncias Psicotrópicas, na qual foram acrescentadas ao rol de drogas narcóticas (ópio, cannabis e cocaína) as drogas psicotrópicas, sob o argumento de que também produziam efeitos danosos e, portanto, necessitavam controle. Sob o mesmo fundamento, essa Convenção repetiu as linhas gerais do conteúdo da Convenção Única.

${ }^{17} \mathrm{Em} 1988$ foi elaborada a Convenção das Nações Unidas contra o Tráfico Ilícito de Entorpecentes e Substâncias Psicotrópicas, ampliando o controle internacional antidrogas e marcando o problema como uma responsabilidade coletiva global no sentido da repressão. Pretendeu-se evidenciar uma resposta da comunidade internacional ao aumento da produção e do tráfico de drogas ilícitas, cujas medidas preconizadas por essa Convenção de Viena não se limitavam à questão do tráfico, incluindo também alguns dos delitos diretamente relacionados às drogas, como lavagem de dinheiro e desvio de precursores químicos.

${ }^{18}$ OLMO, Rosa Del. A face oculta da droga. Trad. Tereza Ottoni. Rio de Janeiro: Revan, 1990, p. 69.
} 
seu custo para o consumidor". ${ }^{19}$ Desse modo, são traçadas estratégias de eliminação das drogas antes de chegarem aos Estados Unidos e de eliminação dos traficantes, aumentando a participação intervencionista norte-americana no exterior, especialmente na América Latina.

A partir da década de 1980, os Estados Unidos utilizam o combate às drogas como eixo central de sua política no continente, passando a difundir, segundo Batista, termos como "narcoguerrilha" e "narcoterrorismo", em clara simbiose com seus "inimigos externos". As drogas, então, passam a constituir o eixo das políticas de segurança nacional nos países atrelados a Washington, de modo que, como registra a autora, os países andinos se transformam em campos de batalha e suas cidades em mercados brutalizados para o varejo residual das drogas ilícitas. ${ }^{20}$

No plano nacional, há noticias de que as primeiras legislações que dispuseram sobre a incriminação das drogas remontam às Ordenações Filipinas $(1603)^{21}$, seguidas por diversas outras, como o Código Penal Republicano $(1890)^{22}$, que dispôs expressamente (em seu art. 159) sobre a proibição de substâncias consideradas venenosas. Este, posteriormente revogado, deu lugar a uma concepção sanitária de controle das drogas, tendo em vista que o consumo de tais substâncias não era considerado massivo, mas ligado a determinados grupos sociais e sem significação econômica.

Contudo, o instrumento ideológico dos Estados Unidos é recepcionado pelo Brasil ${ }^{23}$, resultando na Doutrina de Segurança Nacional que reconhece como “inimigos internos" todos aqueles associados aos comunistas, os quais, posteriormente, dão lugar aos traficantes de drogas, como inimigos a serem combatidos pelo modelo de política criminal beligerante. Percebe-se, assim, que a militarização do controle das drogas guarda relação direta com a

${ }^{19}$ OLMO, Rosa Del. A face oculta da droga. Trad. Tereza Ottoni. Rio de Janeiro: Revan, 1990, p. 65.

20 BATISTA, Vera Malaguti. 0 Tribunal de Drogas e o Tigre de Papel. Disponível em: <http://www.mundojuridico.adv.br>. Acesso em: 03 set.2013.

${ }^{21}$ Título LXXXIX: "Que ninguém tenha em sua casa rosalgar, nem o venda, nem outro material venenoso". Para mais detalhes, consultar: Ordenações Filipinas On-line. Disponível em: <http://www1.ci.uc.pt/ihti/proj/filipinas/>. Acesso em: 05 set.2013.

22 TITULO III (Dos crimes contra a tranquilidade pública), Capítulo III (Dos Crimes Contra a Saúde Pública). "Art. 159. Expôr à venda, ou ministrar, substancias venenosas, sem legitima autorização e sem as formalidades prescriptas nos regulamentos sanitarios: Pena - de multa de $200 \$$ a $500 \$ 000 "$. Disponível em: <http://www6.senado.gov.br/legislacao/ListaPublicacoes.action?id=66049>. Acesso em: 05 set.2013.

${ }^{23}$ A partir do Estado Novo, em 1946, surge um eixo moralizante aderido ao discurso da droga, perdurando até 1964, ano do golpe militar, momento em que ocorre a ruptura do modelo de política criminal, transmudando-se do sanitário para o bélico. No contexto internacional, a partir dessa década, as drogas (como maconha, LSD etc.) adquiriram uma conotação libertária, associada a movimentos de contestação e de manifestações políticas por democracia. 
militarização ideológica da segurança, numa visão maniqueísta entre o bem e o mal, causadora de inúmeras violações aos direitos humanos fundamentais.

Essa política criminal maniqueísta reflete o contexto mundial, na medida em que países pobres representam os fornecedores de drogas, identificados como traficantes, considerados criminosos que devem ser rigorosamente penalizados e controlados, enquanto que países ricos representam os consumidores, considerados vítimas, doentes e dependentes que devem receber tratamento.

Os contornos de guerra dados à política repressiva às drogas ilícitas, em que o inimigo do Estado - o traficante - deve ser combatido e eliminado, promovem uma situação na qual as instituições do Sistema de Justiça e os operadores jurídicos procuram legitimar o discurso da construção do Estado de Polícia em detrimento do Estado de Direito, com movimentos de “Tolerância Zero" e de "Lei e Ordem”, sob o manto de defesa da sociedade.

Não obstante, o discurso proibicionista e criminalizador que nutre o sistema penal mostra sinais, cada vez mais perceptíveis, do fracasso de suas funções declaradas de controle da criminalidade, do consumo e do tráfico de drogas, inclusive reconhecido pela própria Organização das Nações Unidas - ONU, quanto à sua utópica intenção de construir "um mundo livre das drogas".

A constatação atual é de que "um mundo livre das drogas" não apenas não foi alcançado como também o combate repressivo dirigido à sua eliminação resultou em consequências sociais desastrosas, com o aumento da violência, da exclusão, da população prisional e da mortalidade especialmente juvenil.

Ainda assim, no centro das soluções político-jurídicas contraditórias se destacam a Constituição Federal de 1988, que estabelece que o tráfico de drogas configura crime inafiançável e insuscetível de graça e anistia, e a Lei de Crimes Hediondos (Lei 8.072/90), que ratifica a opção pelo aumento da repressão criminal e pelo encarceramento.

Com a criação da Lei $n^{\circ} 11.343 / 06$, que instituiu o SISNAD (Sistema Nacional de Políticas Públicas sobre Drogas), revogando a Lei $n^{\circ} 6.368 / 76$, optou-se pela despenalização do consumidor de drogas, no intuito de retirar da mira repressiva do Estado a massa de jovens consumidores provenientes das classes média e alta. Não obstante o avanço legislativo, o discurso de repressão às drogas ilícitas mantém a dicotomia social e reforça o discurso médico- 
jurídico que diferencia usuário e traficante, ao definir a observância de prevenção ao uso indevido e de repressão ao tráfico. ${ }^{24}$

No campo da produção e do comércio, as drogas ilícitas atendem a uma demanda de consumidores como ocorre com qualquer outra mercadoria, ou seja, encontram-se inseridas na lógica que preside a relação econômica na sociedade capitalista. Na lição de Karam, as atividades de produção, distribuição e consumo dessas substâncias representam atividades econômicas que, em sua essência, não diferem de quaisquer outras atividades realizadas no mercado produtor, distribuidor e consumidor de bens ou serviços. ${ }^{25}$ No entanto, a intervenção do sistema penal, por meio da criminalização de condutas relacionadas à produção e à distribuição dessas mercadorias, transforma tais atividades na linguagem demonizadora de "tráfico de drogas" e de "crime organizado".

Outro ponto interessante revelado pela Criminologia crítica diz respeito ao fato de que não são as drogas que, necessariamente, geram violência e nem os consumidores os responsáveis pela violência de traficantes. Consoante leciona Karam, os consumidores respondem apenas pela existência do mercado, assim como são consumidores de quaisquer produtos, de maneira que o responsável pela violência é o Estado, ao criar a ilegalidade e, consequentemente, gerar criminalidade e violência. ${ }^{26}$

No entanto, a figura do "inimigo" recai sobre os "empresários" e "trabalhadores" do comércio de drogas ilícitas, demonizados como "traficantes", que vivem nas favelas e periferias das cidades, sustentando o modelo repressivo que cumpre a função de encarceramento das populações excluídas do mercado consumidor.

Se, por um lado, há enormes custos sociais decorrentes da criminalização das drogas ilícitas e dos escassos efeitos da política criminal adotada sobre a oferta e demanda, por outro, há enormes vantagens para os especuladores do sistema financeiro. Conforme salienta Karam, amparada em dados da Organização das Nações Unidas - ONU, o mercado das drogas ilícitas

\footnotetext{
${ }^{24}$ Vale ressaltar, por oportuno, que no Brasil as drogas ilícitas somente são proibidas porque figuram em uma lista editada por ato administrativo de autoridade sanitária, cujo rol de substâncias possui função de complementar a norma criminalizadora. Uma vez retirada determinada droga da mencionada lista, aquela deixa de configurar ilicitude penal.

${ }^{25}$ KARAM, Maria Lúcia. Proibições, riscos, danos e enganos: as drogas tornadas ilícitas. Col. Escritos sobre liberdade, Vol. 3. Rio de Janeiro: Lumen Juris, 2009, p. 35.

${ }^{26}$ KARAM, Maria Lúcia. Proibições, riscos, danos e enganos: as drogas tornadas ilícitas. Col. Escritos sobre liberdade, Vol. 3. Rio de Janeiro: Lumen Juris, 2009, p. 41.
} 
movimenta cerca de 500 bilhões de dólares anualmente. ${ }^{27}$ Porém, considerando que os lucros desse negócio operam num mercado paralelo, é possível que atualmente os números já estejam subestimados. Nesse sentido, também não seria legítimo falar apenas em fracasso da política de controle das drogas.

À semelhança do que ocorre com a instituição carcerária, criminólogos críticos denunciam que o discurso proibicionista das drogas contém funções declaradas que não se realizam e funções latentes que se concretizam. ${ }^{28}$ Seguindo o pensamento de Foucault, a partir da crítica ao cárcere, deve-se deixar de lado a perspectiva ideológica de "fracasso" e utilizar a ideia de "sucesso", relegando a um segundo plano as funções declaradas para interpretar o fenômeno através de suas funções reais.

Nesse universo de pensamentos, englobando fenômenos políticos, econômicos, sociais e de saúde pública, a problemática das drogas ilícitas, sobretudo no contexto brasileiro, revela o quanto o tema não é tratado com a devida seriedade, imperando o desconhecimento, a desinformação, o sensacionalismo midiático, a estigmatização, a seletividade, a desigualdade e a criminalização da pobreza. Aliás, percebe-se inclusive um discurso que ignora a necessidade de certos indivíduos fugirem dos seus problemas socioafetivos, produzidos, não raro, pela realidade de abandono, desemprego e exclusão social em que sobrevivem, bem como a história do controle político das contraculturas que ameaçam as sociedades norte-americana e europeia, dando azo a oportunidades de intervenção em outros países em busca da manutenção do poder internacional.

Mais do que isso, a política pública beligerante contra as drogas impulsiona o encarceramento em massa, o controle social e a violência, conforme se verificará a seguir em estatísticas.

\footnotetext{
${ }^{27}$ KARAM, Maria Lúcia. "Guerra às drogas" e criminalização da pobreza. In: ZILIO, Jacson; BOZZA, Fábio (Org.). Estudos críticos sobre o sistema penal: homenagem ao Professor Doutor Juarez Cirino dos Santos por seu $70^{\circ}$ aniversário. Curitiba: LedZe Editora, 2012, p. 692.

${ }_{28}$ BARATTA, Alessandro. Introducción a una sociología de la droga: problemas y contradicciones del control penal de las drogodependencias. p. 216-217. Disponivel em: <http:/ / www.revistajuridicaonline.com/index.php?option=com_content\&task=view\&id=283\&ltemid=27> Acesso em: 04 out.2013.
} 


\section{POLÍTICA PÚBLICA DE ENCARCERAMENTO EM MASSA E CONTROLE SOCIAL}

Dos argumentos expostos até aqui, extrai-se que a política adotada no combate às drogas obedece a interesses econômicos globalizados. Assim, a fim de compreender a situação carcerária relacionada às drogas no contexto nacional, por questão didática e de atenção aos objetivos inicialmente formulados no presente estudo, utilizar-se-ão estatísticas referentes ao tráfico de drogas.

Antes, porém, cumpre registrar que a atual política pública carcerária levada a cabo no Brasil é articulada de forma improvisada, com planejamento precário e da mesma maneira como parece ser conduzida a política criminal de combate às drogas. O que se extrai das poucas informações que chegam até nós pela mídia e pelas produções acadêmicas é que existe reduzido número de vagas, insalubridade, problemas com ventilação, iluminação, falta de atividades educativas e profissionalizantes, baixa preparação técnica dos agentes públicos que atuam nos presídios, falta de segurança, baixa remuneração, formação de facções criminosas dentro do cárcere, entre outros. E esse processo caótico se inicia com a débil política de segurança pública adotada pelo Poder Executivo, que se traduz meramente em repressão, desprezando a interdisciplinaridade, ou seja, o envolvimento de outras áreas do conhecimento, como a educação, os esportes, a saúde etc. no intuito de solucionar os problemas.

O Executivo, responsável pela administração do sistema prisional, não investe suficientemente (em quantidade e qualidade) nas condições estruturais, permitindo a superlotação das unidades. A superlotação representa um dos fatores que gera uma série de outros problemas estruturais, como condições de higiene, alimentação e comportamento, apenas para citar alguns. Além disso, há um descompasso na relação entre o número de presos e de funcionários. Some-se, ainda, o fato de que historicamente a prisão no Brasil é o destino da população pobre ou em situação de vulnerabilidade, o que contribui para que políticos e governantes pouco se importem com a população encarcerada. Seguramente, se entre os presos dessas masmorras estivessem grandes empresários e políticos que praticaram crimes de corrupção, sonegação de tributos, poluição ambiental, crimes eleitorais, por exemplo, a situação seria diferente.

Mas o Poder Executivo tem apenas uma parte da responsabilidade pelo caos que se instalou no país, pois administra também aquilo que foi determinado no âmbito do Poder 
Judiciário. Logo, o Judiciário tem sua significativa parcela de culpa, ao encampar ideologicamente uma política criminal de encarceramento em massa, isto é, no sentido de que a criminalidade se resolve com condenações à prisão. Ao mesmo tempo, falta agilidade nos processos, há excesso de permanência de presos sem julgamento definitivo, entre outras situações que não são novidades.

De maneira geral (pois, reconhece-se que há exceções), a atuação dos atores jurídicos frente à garantia dos direitos fundamentais - entre os quais estão policiais, advogados, juízes e promotores - deixa muito a desejar, especialmente em razão da deficitária estrutura do Poder Judiciário e da legislação que, não raro, deixa de ser cumprida em sua integralidade, mormente quanto aos direitos fundamentais dos presos. 0 simples respeito aos direitos fundamentais pode contribuir imensamente para a construção de um ambiente que ajude na recuperação do apenado visando o seu retorno à sociedade.

No tocante à estratégia de combate às drogas, por exemplo, a lógica é a mesma - a prisão. A falha ou o equívoco passa pela política de solução dos problemas com a prisão, quando, na verdade, esta já é um problema em si historicamente conhecido pelos estudiosos da matéria, agravado pela falta de investimentos em unidades que garantam um mínimo de dignidade humana aos presos. Essa é a política pública carcerária em curso nesse país, que pode ser resumida pela palavra “descaso" e demonstrada pelas estatísticas.

Tendo em vista os dados estatísticos ${ }^{29}$ fornecidos pelo Censo Demográfico do Instituto Brasileiro de Geografia e Estatística - IBGE e pelo Ministério da Justiça, compreendidos entre 2000 e 2011, verifica-se que a população carcerária nacional aumentou significativamente, ainda que considerado o crescimento do número de habitantes no mesmo período, de acordo com a tabela a seguir:

\footnotetext{
29 Para o contexto do presente trabalho, importa compreender a lógica da prisão em comparação empírica, especialmente com dados estatísticos. Acompanha-se aqui a visão de Andrade quando diz não gostar de estatísticas "porque elas nos ensinam a contar vidas humanas matematicamente, roubando-lhes a biografia e a história", mas que quando produzidas e utilizadas com responsabilidade ética representam "poderoso instrumento de aproximação (não retratação) da realidade empírica". ANDRADE, Vera Regina Pereira de. Pelas mãos da criminologia: o controle penal para além da (des)ilusão. Rio de Janeiro: Revan, 2012, p. 307.
} 


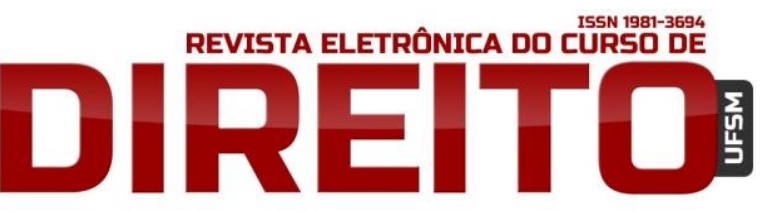

POLÍTICA PÚBLICA CARCERÁRCIA: UMA INSTITUCIONALIZADA VIOLAÇÃO DE DIREITOS FUNDAMENTAIS IMPULSIONADA PELA CRIMINALIZAÇÃO DAS DROGAS

TABELA 1: Dados da população carcerária no Brasil, incluída em todos os Grupos de crimes e no "Grupo Entorpecentes", entre dezembro de 2000 e dezembro de 2011.

\begin{tabular}{|c|c|c|c|c|c|c|c|c|c|c|c|c|}
\hline POPULAÇÃO & ষ্ণ & ర్ల & ঠ్రి & గ్రి & ষ্ণ & 용 & 윰 & 옹 & 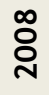 & 용 & 응 & 휴 \\
\hline Total de habitantes* & 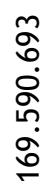 & ' & ' & ' & & ' & ' & ' & ' & ' & 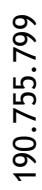 & \\
\hline $\begin{array}{c}\text { Total de reclusos incluídos } \\
\text { em todos } \\
\text { os Grupos de crimes }\end{array}$ & $\stackrel{\substack{n \\
\stackrel{n}{N}}}{\underset{N}{N}}$ & 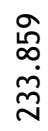 & $\begin{array}{l}\stackrel{n}{\sim} \\
\stackrel{m}{\tilde{m}}\end{array}$ & 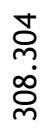 & $\begin{array}{l}\infty \\
\stackrel{\infty}{m} \\
\stackrel{m}{m} \\
m\end{array}$ & 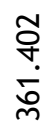 & $\begin{array}{l}\stackrel{N}{\sim} \\
\text { ơ }\end{array}$ & 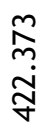 & 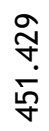 & 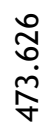 & 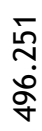 & $\begin{array}{l}\underset{\infty}{\infty} \\
\stackrel{+}{\leftarrow} \\
\text { in }\end{array}$ \\
\hline $\begin{array}{c}\text { Índice de encarceramento } \\
\text { x } 100 \text { mil } \\
\text { habitantes }\end{array}$ & 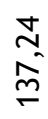 & ' & ' & ' & ' & ' & ' & ' & ' & ' & ז & \\
\hline $\begin{array}{c}\text { Total de reclusos incluídos } \\
\text { apenas no } \\
\text { “Grupo Entorpecentes” }\end{array}$ & ' & ' & ' & ' & & $\begin{array}{l}\stackrel{\circ}{ } \\
\infty \\
\stackrel{\sim}{\sim}\end{array}$ & $\underset{\text { f }}{\stackrel{N}{f}}$ & $\begin{array}{l}\text { ơ } \\
\text { ம் } \\
\text { மூ }\end{array}$ & $\stackrel{\Gamma}{\stackrel{N}{N}}$ & $\begin{array}{l}\hat{\sigma} \\
\dot{\sigma} \\
\sigma\end{array}$ & $\begin{array}{l}\bar{\sigma} \\
\dot{\sigma} \\
\stackrel{0}{\circ}\end{array}$ & $\underset{\text { in }}{\stackrel{7}{*}}$ \\
\hline
\end{tabular}

Fonte: InfoPen - Estatística. Disponível em:

<http://portal.mj.gov.br/data/Pages/MJD574E9CEITEMIDC37B2AE94C6840068B1624D28407509CPTBRIE.htm>. Acesso em: 05 out.2013.

${ }^{*}$ Censo demográfico do IBGE. Disponível em:

<http://www.ibge.gov.br/home/estatistica/populacao/censo2010/tabelas_pdf/Brasil_tab_1_8.pdf>. Acesso em: 05 out.2013.

Os referidos dados apontam que no Brasil, entre os anos 2000 e 2010, o total de habitantes aumentou de 169.590 .693 (cento e sessenta e nove milhões, quinhentos e noventa mil, seiscentos e noventa e três) para 190.755 .799 (cento e noventa milhões, setecentos e cinquenta e cinco mil, setecentos e noventa e nove), um acréscimo correspondente a 12,48\%, enquanto que a população carcerária em geral aumentou de 232.755 (duzentos e trinta e dois mil, setecentos e cinquenta e cinco) para 496.251 (quatrocentos e noventa e seis mil, duzentos e cinquenta e um) reclusos, um acréscimo de 113,20\%. Tomado o índice de encarceramento para cada 100 (cem) mil habitantes, verifica-se o aumento de 137,24 para 260,14, correspondente a $89,55 \%$, o que significa que a população carcerária, aproximadamente, dobrou em apenas 10 (dez) anos no Brasil. 
A propósito, cabe registrar que com esses índices o Brasil atualmente ocupa a $4^{a}$ maior população carcerária do mundo, ficando somente atrás em número de detentos para os Estados Unidos (2,2 milhões), a China (1,6 milhão) e a Rússia (740 mil). ${ }^{30}$

As estatísticas revelam também que os reclusos por tráfico de drogas, enquadrados no "Grupo Entorpecentes", correspondiam a 9,09\% (32.880) do total de reclusos (361.402) em 2005, enquanto que em 2010 passaram a representar 21,45\% (106.491) do total de reclusos (496.251). Partindo desse contexto numérico, conclui-se que a população encarcerada pela prática de tráfico de drogas mais do que dobrou no mesmo período, evidenciando a opção político-criminal de incremento punitivo em nível nacional.

0 que os dados de encarceramento pela prática de delitos em geral em nível nacional evidenciam é uma política pública de encarceramento massivo como mecanismo de controle social punitivo. A gravidade da situação chama mais ainda a atenção quando constatada a barbárie do sistema penal no tocante ao controle específico dirigido ao controle das drogas, cujo crescimento do aprisionamento mais do que dobrou em 5 (cinco) anos (2005-2010). ${ }^{31}$

Outra evidência do controle social punitivo pode ser identificada quando analisado o grau de instrução da população encarcerada, situação em que o modelo de política criminal adotado em relação às drogas ilícitas revela a influência do poder do mercado e a redução do Estado Social, recaindo o controle punitivo sobre as classes pobres, desfavorecidas ou vulneráveis $^{32}$. É o que se verifica a partir dos seguintes dados estatísticos fornecidos pelo Ministério da Justiça:

\footnotetext{
${ }^{30}$ Segundos dados da organização não governamental Centro Internacional para Estudos Prisionais (ICPS).

${ }^{31}$ Para um estudo mais aprofundado, considerando o encarceramento da população feminina, os indivíduos submetidos ao cumprimento de penas e medidas alternativas e a relação existente entre o controle social exercido pelo capital e pelo sistema penal, confrontar: SILVA, Marco Aurélio Souza da. 0 controle social punitivo antidrogas sob a perspectiva da Criminologia crítica: a construção da criminalidade do tráfico de drogas nas decisões judiciais. Rio de Janeiro: Lumen Juris, 2013; SILVA, Marco Aurélio Souza da. 0 controle social punitivo antidrogas sob a perspectiva da criminologia crítica: a construção do traficante nas decisões judiciais em Santa Catarina. 372 f. Dissertação (Mestrado em Direito) - Programa de PósGraduação em Direito da Universidade Federal de Santa Catarina, Florianópolis, 2012.

${ }^{32}$ A vulnerabilidade, segundo Bianchini, é entendida como a reduzida ou inexistente capacidade de o indivíduo ou grupo social deliberar sobre sua situação de risco, estando ligada diretamente a fatores culturais, sociais, políticos, econômicos e biológicos. BIANCHINI, Alice. Comentários ao art. 18. In: GOMES, Luiz Flávio et al. Lei de drogas comentada: Lei 11.343, de 23.08.2006. 4. ed. rev., atual. e ampl. São Paulo: Revista dos Tribunais, 2011, p. 75.
} 
ISSN 1981-3694

(DOI): $10.5902 / 1981369413018$

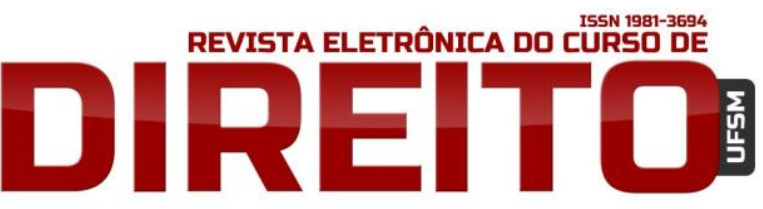

POLÍTICA PÚBLICA CARCERÁRCIA: UMA INSTITUCIONALIZADA VIOLAÇÃO DE DIREITOS FUNDAMENTAIS IMPULSIONADA PELA CRIMINALIZAÇÃO DAS DROGAS

TABELA 2: Dados referentes ao grau de instrução dos presos no Brasil entre 2005 e 2011.

\begin{tabular}{|c|c|c|c|c|c|c|c|}
\hline GRAU DE INSTRUÇÃO & 옹 & 윰 & స్ & ஓ̊ํํ & 유 & 응 & $\frac{\pi}{\grave{n}}$ \\
\hline Analfabeto & $\begin{array}{l}\underset{\infty}{\infty} \\
\check{E}\end{array}$ & $\begin{array}{l}\stackrel{g}{\mathrm{j}} \\
\stackrel{\mathrm{\sigma}}{\sigma}\end{array}$ & 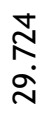 & $\begin{array}{l}\underset{N}{\sim} \\
\stackrel{\infty}{\sim}\end{array}$ & $\begin{array}{l}\bar{g} \\
\dot{0} \\
\dot{N}\end{array}$ & 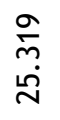 & $\underset{\stackrel{+}{+}}{\stackrel{\sim}{v}}$ \\
\hline Alfabetizado & $\begin{array}{l}\bar{\sigma} \\
\dot{\sigma}\end{array}$ & $\begin{array}{l}\stackrel{m}{8} \\
\text { f }\end{array}$ & $\underset{\text { Ñ}}{\stackrel{\sim}{\sim}}$ & $\begin{array}{l}\text { षे } \\
\text { ○े } \\
\text { f }\end{array}$ & $\begin{array}{l}\bar{N} \\
\text { ণ் }\end{array}$ & $\begin{array}{l}\stackrel{m}{\infty} \\
\stackrel{\infty}{\text { กீ }}\end{array}$ & $\begin{array}{l}\hat{\gamma} \\
\infty \\
\infty\end{array}$ \\
\hline $\begin{array}{l}\text { Ensino Fundamental } \\
\text { Incompleto }\end{array}$ & $\begin{array}{l}\text { م } \\
\text { مீ } \\
\text { n் }\end{array}$ & $\begin{array}{l}\stackrel{\text { N }}{N} \\
\stackrel{ }{\rightleftharpoons}\end{array}$ & $\begin{array}{l}\underset{n}{N} \\
\tilde{n} \\
\stackrel{0}{0}\end{array}$ & $\begin{array}{l}\stackrel{0}{\sigma} \\
\underset{N}{\sigma}\end{array}$ & $\begin{array}{l}\stackrel{+}{+} \\
\stackrel{2}{0} \\
\stackrel{\infty}{=}\end{array}$ & $\begin{array}{l}\stackrel{\infty}{\sigma} \\
\text { б. }\end{array}$ & $\begin{array}{l}\stackrel{0}{\infty} \\
\dot{\infty} \\
\stackrel{0}{N}\end{array}$ \\
\hline $\begin{array}{l}\text { Ensino Fundamental } \\
\text { Completo }\end{array}$ & $\begin{array}{l}\text { م) } \\
\text { O } \\
\stackrel{\sim}{N}\end{array}$ & $\begin{array}{l}\bar{D} \\
\dot{m}\end{array}$ & $\begin{array}{l}\infty \\
\infty \\
\stackrel{\sim}{F}\end{array}$ & $\begin{array}{l}\underset{\sim}{ } \\
\stackrel{\sigma}{\sigma}\end{array}$ & $\begin{array}{l}\bar{\infty} \\
\text { ஸ் }\end{array}$ & $\begin{array}{l}\underset{N}{\infty} \\
\text { N } \\
\text { గn }\end{array}$ & $\frac{\overline{0}}{\stackrel{\circ}{\circ}}$ \\
\hline $\begin{array}{l}\text { Ensino Médio } \\
\text { Incompleto }\end{array}$ & $\begin{array}{l}\stackrel{5}{n} \\
\stackrel{n}{n}\end{array}$ & $\begin{array}{l}\stackrel{\ln }{0} \\
\stackrel{n}{N}\end{array}$ & $\frac{\stackrel{\text { f }}{\leftarrow}}{\stackrel{\text { f }}{m}}$ & $\frac{\bar{\Gamma}}{\dot{\sigma}}$ & $\begin{array}{l}\text { 寸 } \\
\dot{J}\end{array}$ & 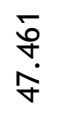 & $\begin{array}{l}\text { ડ̊ } \\
\text { กิ }\end{array}$ \\
\hline $\begin{array}{l}\text { Ensino Médio } \\
\text { Completo }\end{array}$ & $\begin{array}{l}\stackrel{n}{N} \\
m \\
0 \\
0\end{array}$ & 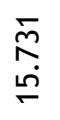 & $\begin{array}{l}\infty \\
\stackrel{N}{\infty} \\
\dot{\sim}\end{array}$ & $\begin{array}{l}\underset{N}{\sigma} \\
\stackrel{\sim}{N}\end{array}$ & $\frac{N}{\grave{0}}$ & $\begin{array}{l}\bar{\sigma} \\
\stackrel{0}{0} \\
\stackrel{m}{ }\end{array}$ & م⿱⺈⿵⺆⿻二丨冂 \\
\hline $\begin{array}{l}\text { Ensino Superior } \\
\text { Incompleto }\end{array}$ & 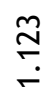 & $\stackrel{+}{\infty}$ & $\underset{\dot{m}}{\stackrel{\varpi}{m}}$ & $\stackrel{\infty}{\frac{\infty}{n}}$ & \begin{tabular}{c}
\multirow{2}{*}{} \\
i
\end{tabular} & $\frac{\dot{m}}{\dot{m}}$ & $\stackrel{\circ}{\stackrel{\circ}{\circ}}$ \\
\hline $\begin{array}{l}\text { Ensino Superior } \\
\text { Completo }\end{array}$ & $\stackrel{\Re}{\infty}$ & $\stackrel{\stackrel{n}{\leftarrow}}{\leftarrow}$ & 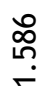 & 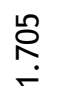 & $\stackrel{n}{\stackrel{n}{r}}$ & $\underset{\infty}{\stackrel{\infty}{-}}$ & $\stackrel{\circ}{\circ}$ \\
\hline $\begin{array}{c}\text { Ensino acima de Superior } \\
\text { Completo }\end{array}$ & $\mp$ & $\stackrel{m}{\sim}$ & in & $\infty$ & 응 & $\mathfrak{N}$ & กำ \\
\hline
\end{tabular}

Fonte: InfoPen - Estatística. Disponível em:

<http://portal.mj.gov.br/data/Pages/MJD574E9CEITEMIDC37B2AE94C6840068B1624D28407509CPTBRIE.htm>. Acesso em: 07 out.2013.

A partir dos dados oficiais referentes ao grau de instrução da população carcerária no Brasil entre 2005 e 2011, observa-se a predominância absoluta de presos com ensino fundamental incompleto, quando comparados com os de ensino superior completo. Mais dramática, ainda, é a situação verificada quando comparado o número absurdamente predominante de presos sem curso superior com o de nível universitário.

Essas comparações evidenciam um processo de seleção de indivíduos pertencentes às classes desfavorecidas, ou seja, com maior probabilidade de criminalização. É nesse processo de 
redução do Estado social e de fortalecimento do Estado penal que resta descortinado o controle social do trabalho precário e das classes vulneráveis, consideradas perigosas e fonte irradiadora da criminalidade.

A breve análise das estatísticas desnuda o controle social e o estado atual do sistema carcerário, que na visão de Carvalho demonstra a forma como a sociedade brasileira resolveu historicamente suas questões sociais, étnicas e culturais, optando pela via da exclusão, da neutralização e da anulação da alteridade. Os dados ainda revelam, na mesma linha do criminólogo, que "a responsabilidade pela densificação do punitivismo e pela criação do imenso contingente de pessoas presas é dos atores que dão vida, diariamente, ao sistema punitivo". ${ }^{33}$

Portanto, extrai-se do universo estatístico analisado que o controle social antidrogas mantém uma linha de política pública criminal representada pelo fracasso (ou "sucesso") no encarceramento em massa, operado de modo seletivo, excludente e desigual, segundo denunciado pela Criminologia crítica. Conforme salientado no decorrer do trabalho, a análise histórica e crítica do sistema punitivo revela a ambiguidade do discurso dos fins sociais da pena de prisão, da retribuição, da prevenção geral e especial, sustentado pelos defensores da instituição carcerária e, consequentemente, da Criminologia positivista.

Infelizmente, a política de segurança pública de combate à criminalidade, notadamente relacionada às drogas ilícitas, continua sendo o foco principal dos governos federal e estaduais, amparada em leis que multiplicam e agravam as infrações penais com pena privativa de liberdade, no aumento da repressão policial e na construção de novas penitenciárias, intensificando a violência institucional e o do controle social.

Ao contrário, uma política de reintegração social dos autores de delitos deve ter como objetivo imediato a redução de encarceramento e a ampliação de penas alternativas, em face da institucionalizada violação de direitos fundamentais promovida pelo sistema carcerário.

\section{O SISTEMA CARCERÁRIO E A INSTITUCIONALIZADA VIOLAÇÃO DE DIREITOS FUNDAMENTAIS}

A despeito das análises até aqui realizadas acerca do sistema penal, da política pública antidrogas e das estatísticas de encarceramento em massa, cumpre a seguir registrar as

${ }^{33}$ CARVALHO, Salo de. Substitutivos penais na era do grande encarceramento. In: ABRAMOVAY, Pedro Vieira; BATISTA, Vera Malaguti (Org.). Depois do grande encarceramento. Rio de Janeiro: Revan, 2010, p. 374-375; 377. 
consequências de um sistema carcerário violador de direitos fundamentais, tolerado pelas instituições públicas.

Há pouco tempo, conforme amplamente divulgado pela mídia, o Ministro da Justiça José Eduardo Cardozo chamou o sistema carcerário brasileiro de medieval e disse que preferia morrer a nele cumprir pena. Não é de hoje que reportagens divulgadas pela imprensa e estudos acadêmicos denunciam que os presos se encontram em verdadeiras masmorras, em condições visivelmente violadoras de direitos fundamentais, que vão desde problemas estruturais das edificações, passando por situações de superlotação, fome, tortura, maus-tratos, ausência de itens básicos de higiene pessoal, insalubridade das celas, falta de ventilação, escasso acesso à água, extorsões, confinamento em contêineres, mulheres aprisionadas junto com homens, mistura de presos provisórios (sem julgamento) com presos condenados, controle por facções criminosas, abusos sexuais, até a morte.

Apesar de noticiado que a grande maioria das prisões representa verdadeiros depósitos de seres humanos, que não dispõem de serviços de assistência médica, jurídica e social suficientes, o sistema carcerário brasileiro ainda se mantém nesse estado deplorável porque, em regra, conta com um significativo grau de conivência de instituições públicas e seus agentes (Judiciário, Ministério Público, Tribunal de Contas, Agentes prisionais etc.), bem como da própria sociedade.

O exemplo recente foi a crise que eclodiu no Complexo Penitenciário de Pedrinhas, em São Luís (MA), cuja situação carcerária ganhou repercussão nacional com a divulgação pela imprensa. No interior do presídio, destacou-se a situação de caos, inclusive com decapitação de detentos por confrontos entre facções rivais. Contudo, a divulgação só ocorreu quando a violência extrapolou os muros da prisão, chamando a atenção para as mazelas do caótico sistema prisional no País, sufocado por sua política de encarceramento em massa.

Ainda que essa abordagem exija uma visão transdisciplinar (política, econômica, sociológica, antropológica etc.), o presente estudo teoriza a problemática a partir dos enfoques criminológico e constitucional. Como já trabalhada a questão criminológica anteriormente, passa-se agora a uma breve abordagem constitucional do fenômeno.

A Constituição Federal de 1988 é pródiga na fixação de direitos e garantias que se estendem como feixes de luzes para as legislações inferiores no ordenamento, orientados pela dignidade da pessoa humana. Assim, não apenas os cidadãos em liberdade, mas também os encarcerados possuem direitos básicos (não atingidos pela perda da liberdade), como direito à vida, à saúde, à integridade física e moral, à educação, ao trabalho etc. A estes, ainda, resta o 
direito ao cumprimento de pena em estabelecimentos específicos, de acordo com a natureza do delito, idade, sexo etc., sendo vedadas penas cruéis e degradantes. ${ }^{34}$

Não se pode perder de vista que os direitos fundamentais foram realçados na sociedade quando foi invertida a tradicional relação entre Estado e indivíduo e reconhecida a ideia de que o indivíduo possui, primeiro, direitos, e, depois, deveres perante o Estado, assim como os direitos que o Estado possui perante o indivíduo têm por objetivo melhor cuidar das necessidades dos cidadãos. ${ }^{35}$

Ainda que não se possa considerar que o Brasil efetivamente tenha atingido um Estado de Bem-estar social, ao menos se reconhece ter sido influenciado pela nova ordem constitucional, especialmente no tocante à profunda carga de direitos fundamentais ${ }^{36}$, modelo que se materializou somente com a Constituição da Federal de 1988.

De outra parte, é cediço que a mera previsão constitucional de preceitos fundamentais, por si só, não se faz suficiente para enfrentar a desigualdade e a exclusão social histórica e estruturalmente construída ao longo de décadas, impulsionada pelo capitalismo neoliberal e materializada nas estatísticas prisionais. A Constituição preceitua, por exemplo, que dentre os seus objetivos está a erradicação da pobreza e da marginalização e a redução das desigualdades sociais e regionais (art. $3^{\circ}$, III). Contudo, para além da esfera estritamente dogmática ou jurídico-positiva, é necessário levar em consideração que diversos direitos erigidos a fundamentais, concebidos como aqueles direitos da pessoa humana, reconhecidos e positivados na esfera do direito constitucional, cuja baixa efetividade, especialmente no que

\footnotetext{
${ }^{34}$ Nesse sentido, a leitura dos arts. $1^{\circ}$, III, e $5^{\circ}$, III, XLVII, XLVIII e XLIX da CF/88, do art. 38 do CP e dos arts $3^{\circ}, 40,41,85,88,91$ e 92 da LEP, entre outros, compõem o arcabouço normativo de proteção digna dos encarcerados.

${ }^{35}$ MENDES, Gilmar Ferreira; BRANCO, Paulo Gustavo Gonet. Curso de direito constitucional. 9. ed., rev. e atual., São Paulo: Saraiva, 2014, p. 136.

$36 \mathrm{Em}$ regra, os direitos constitucionalmente reconhecidos e assegurados apresentam uma dupla fundamentalidade: material e formal. Adotando-se a concepção de Sarlet, observa-se que a fundamentalidade formal se desdobra em três elementos: a) os direitos fundamentais se situam no ápice do ordenamento jurídico, sendo normas de superior hierarquia; b) os direitos fundamentais estão submetidos a limites formais (procedimento agravado para sua modificação) e materiais (relacionados às designadas "cláusulas pétreas") para reforma constitucional; e c) as normas definidoras de direitos e garantias fundamentais são imediatamente aplicáveis e vinculam diretamente as entidades estatais e os particulares $\left(\operatorname{art.} 5^{\circ}, \S 1^{\circ}\right)$. Já a fundamentalidade material diz respeito ao conteúdo e à importância dos direitos fundamentais plasmados na Constituição, ou seja, implica a análise da circunstância de conterem, ou não, decisões fundamentais acerca da estrutura do Estado e da sociedade, considerando a posição nestes ocupada pela pessoa humana (SARLET, Ingo Wolfgang; MARINONI, Luiz Guilherme; MITIDIERO, Daniel. Curso de direito constitucional. 3. ed., rev., atual. e ampl. São Paulo: Revista dos Tribunais, 2014, p. 281-282).
} 

CRIMINALIZAÇÃO DAS DROGAS

MARCO AURÉLIO SOUZA DA SILVA

toca aos direitos sociais ${ }^{37}$, geralmente é justificada pela limitada capacidade de prestações do Estado, isso sem contar com as intermináveis discussões acerca de sua aplicação imediata.

Assim, se de um lado o "fator custo" tem sido alegado pelo Poder Executivo para negar a aplicação imediata dos direitos fundamentais sociais de cunho prestacional, especialmente, sob o argumento de que as prestações materiais se encontram sob a reserva das capacidades financeiras do Estado, de outro, tem sido esse argumento desconstituído pelos expressivos gastos públicos em outras áreas menos importantes do ponto de vista da dignidade da pessoa humana (copa do mundo, olimpíadas etc.). Aliás, independentemente de sua dimensão de prestação (direitos positivos) ou de defesa (direitos negativos), seguindo o prestigiado pensamento de $A_{\text {lexy }}{ }^{38}$, o atendimento dos direitos fundamentais (especialmente sociais) implica exigência e concretização da dignidade da pessoa humana, porquanto visa à proteção da pessoa por meio uma existência digna (direito à vida com um mínimo de saúde e bem-estar), mesmo que consideradas as variáveis de satisfação na sociedade nos diversos momentos históricos ${ }^{39}$. É de se lembrar de que é na dignidade da pessoa humana que reside o fundamento principal e o alicerce do conceito material dos direitos fundamentais. Conforme assevera Barroso, a dignidade da pessoa humana é parte do conteúdo dos direitos materialmente fundamentais. ${ }^{40}$

\footnotetext{
${ }^{37}$ No âmbito do sistema de direito constitucional, é possivel afirmar que todos os direitos sociais são fundamentais, independentemente de estarem expressa ou implicitamente positivados, situados ou não no Título II do texto constitucional ou, ainda, previstos em tratados internacionais assinados pelo Brasil. Nesse sentido, vale trazer as lições de Sarlet, ao lembrar que "os direitos fundamentais somente podem ser considerados verdadeiramente fundamentais quando e na medida em que thes é reconhecido (e assegurado) um regime jurídico privilegiado no contexto da arquitetura constitucional" (SARLET, Ingo Wolfgang. Os direitos fundamentais sociais e os vinte anos da Constituição Federal de 1988: resistências e desafios à sua eficácia e efetividade. Revista do Instituto de Hermenêutica Jurídica - RIHJ. Belo Horizonte, Ano 1, $\mathrm{n}^{\circ} 6$, jan./dez. 2008).

${ }^{38}$ Para Alexy, "todo direito a uma ação positiva, ou seja, a uma ação do Estado, é um direito a uma prestação. Nesse sentido, o conceito de direito a prestações é exatamente o oposto do conceito de direito de defesa, no qual se incluem todos os direitos a uma ação negativa, ou seja, a uma abstenção estatal" (ALEXY, Robert. Teoria dos direitos fundamentais. 2. ed., São Paulo: Malheiros Editores, 2011, p. 442).

${ }^{39}$ Vale citar, por oportuna, a posição de Sarlet, para quem os direitos fundamentais podem exercer, inclusive simultaneamente, uma função defensiva ou prestacional, a exemplo do direito à saúde, que será direito negativo quando se cuida de afastar (direito de defesa) eventuais condutas que venham a violar a saúde das pessoas, mas que será direito a prestações (direito positivo) quando se estiver a considerar um direito de acesso aos serviços e bens na área da saúde. 0 mesmo se diga em relação a outros direitos, como à moradia, à educação etc. Nesse contexto, afirma o autor que, em matéria de direitos fundamentais como direitos subjetivos, em verdade o que se tem é um complexo não homogêneo de posições jurídico-subjetivas fundamentais (SARLET, Ingo Wolfgang. O direito fundamental à moradia na Constituição: algumas anotações a respeito de seu contexto, conteúdo e possível eficácia. Revista Brasileira de Direito Público - RBDP, Belo Horizonte, ano 1, n. 2, jul./set. 2003. Disponível em: <http://bid.editoraforum.com.br/bid/PDI0006.aspx?pdiCntd=12524>. Acesso em: 18 fev. 2014).

40 Segundo Barroso, são conteúdos mínimos da dignidade o valor intrínseco da pessoa humana, a autonomia da vontade e o valor comunitário. O valor intrínseco é o elemento ontológico da dignidade,
} 

CRIMINALIZAÇÃO DAS DROGAS

MARCO AURÉLIO SOUZA DA SILVA

Não obstante o crescimento da preocupação com os direitos fundamentais e os direitos humanos ${ }^{41}$, aliada à vasta legislação pertinente, a questão carcerária ainda não encontrou o devido espaço no debate social, talvez em razão do baixo reconhecimento dos referidos direitos e do seu núcleo - a dignidade da pessoa humana - por parte da sociedade, possivelmente em face do senso comum de que tais direitos estão relacionados essencialmente à ordem filosófica (moral, ética, do “ser”), longe de aplicação prática. Ou, ainda, em razão da própria formação da sociedade brasileira, por não se ter consolidado um verdadeiro e concreto modelo constitucional de direitos e garantias. Não raro, os mencionados direitos são vistos como favores ou benesses aos autores das condutas ilícitas.

Partindo-se da ideia de que o reconhecimento da dignidade humana compartilhado por grande parte da sociedade parece estar muito mais relacionado ao "ter" do que ao "ser", essa concepção que encarna os direitos fundamentais pode explicar a tolerância da sociedade

traço distintivo da condição humana, do qual decorre que todas as pessoas são um fim em si mesmas, e não meios para a realização de metas coletivas ou propósitos de terceiros. A inteligência, a sensibilidade e a capacidade de comunicação são atributos únicos que servem de justificação para essa condição singular. Do valor intrínseco decorrem direitos fundamentais como o direito à vida, à igualdade e à integridade física e psíquica. A autonomia da vontade é o elemento ético da dignidade humana, associado à capacidade de autodeterminação do indivíduo, ao seu direito de fazer escolhas existenciais básicas. Ínsita na autonomia está a capacidade de fazer valorações morais e de cada um pautar sua conduta por normas que possam ser universalizadas. A autonomia tem uma dimensão privada, subjacente aos direitos e liberdades individuais, e uma dimensão pública, sobre a qual se apoiam os direitos políticos, isto é, o direito de participar do processo eleitoral e do debate público. Condição do exercício adequado da autonomia pública e privada é o mínimo existencial, isto é, a satisfação das necessidades vitais básicas. E o valor comunitário é o elemento social da dignidade humana, identificando a relação entre o indivíduo e o grupo. Nessa acepção, ela está ligada a valores compartilhados pela comunidade, assim como às responsabilidades e deveres de cada um. Vale dizer: a dignidade como valor comunitário funciona como um limite às escolhas individuais. Também referida como dignidade como heteronomia, ela se destina a promover objetivos sociais diversos, dentre os quais a proteção do indivíduo em relação a atos que possa praticar capazes de afetar a ele próprio (condutas autorreferentes), a proteção de direitos de outras pessoas e a proteção de valores sociais, dos ideais de vida boa de determinada comunidade. Para minimizar os riscos do moralismo e da tirania da maioria, a imposição de valores comunitários deverá levar em conta a) a existência ou não de um direito fundamental em jogo; b) a existência de consenso social forte em relação à questão; e c) a existência de risco efetivo para direitos de terceiros (BARROSO, Luís Roberto. 0 novo direito constitucional brasileiro: contribuições para a construção teórica e prática da jurisdição constitucional no Brasil. 2. reimp., Belo Horizonte: Fórum, p. 326-327).

${ }^{41}$ Por uma questão terminológica, adota-se aqui o entendimento de Sarlet, que sustenta a distinção traçada entre os "direitos fundamentais", considerados aqueles reconhecidos pelo direito constitucional positivo e, portanto, delimitados espacial e temporalmente, e os denominados "direitos humanos", que constituem posições jurídicas reconhecidas na esfera do direito internacional positivo ao ser humano como tal, independentemente de sua vinculação com determinada ordem jurídico-positiva interna (SARLET, Ingo Wolfgang. Os direitos fundamentais sociais na Constituição de 1988. Revista Diálogo Jurídico, Salvador, CAJ - Centro de Atualização Jurídica, v. 1, $\mathrm{n}^{\circ} .1,2001$. Disponível em: <http://www.direitopublico.com.br/pdf_seguro/revista-dialogo-juridico-01-2001-ingo-sarlet.pdf>. Acesso em: 27 out.2013). 
(incluindo as instituições públicas) frente à degradante e desumana situação que se apresenta o sistema carcerário no País. Nesse contexto, se considerado que um indivíduo pertencente às classes desfavorecidas já gozaria de baixo grau de dignidade, o autor de um delito que cumpre pena no sistema não seria titular desse direito (nuclear) fundamental.

A partir dos dados estatísticos demonstrados no tópico anterior (item 3), pode-se constatar o controle social exercido pelo sistema penal, expandido pela criminalização das drogas, em que são vítimas basicamente os indivíduos pertencentes às classes desfavorecidas ou vulneráveis, situação que remete à violação de direitos fundamentais sofridas no sistema carcerário.

O sistema carcerário revela a profunda situação de desigualdade social, política e econômica que marca a sociedade capitalista neoliberal, de modo que a prisão explicita essas desigualdades pelo perfil de sua clientela excluída do mercado de consumo (grande maioria de jovens, negros e pobres moradores da periferia).

Nesse cenário desolador, as instituições públicas possuem um papel importantíssimo, especialmente o Poder Judiciário, o Ministério Público, a Defensoria Pública e o Tribunal de Contas, não só no âmbito da União, mas também dos estados, cada qual no seu âmbito de atribuição. Em apertada síntese, as violações aos direitos fundamentais no sistema carcerário podem, pelo menos, ser minimizadas pela atuação do Poder Judiciário nas determinações de cumprimento das normas, do Ministério Público na fiscalização das leis, da Defensoria Pública na participação ativa da defesa dos direitos e garantias dos necessitados e o Tribunal de Contas na fiscalização da aplicação dos recursos públicos.

Muito embora, de maneira geral, tais instituições se esforcem para desenvolver um bom trabalho, não há dúvidas de que ainda estão longe do ideal na concretização dos preceitos constitucionais, conforme demonstram as estatísticas e o contexto generalizado de violação dos direitos fundamentais no sistema carcerário.

O quadro absurdo do sistema prisional há muito tem sido resultado da ausência de política pública com respeito aos direitos consagrados na Constituição e da omissão do Estado quanto ao oferecimento de condições mínimas de segurança, preservação da integridade física, proteção da vida, promoção da saúde, do trabalho e da educação. O Estado é responsável pelo que ocorre dentro dos estabelecimentos prisionais e deveria ser o primeiro a observar os direitos fundamentais, dentro da concepção de um Estado Constitucional e Democrático de Direito. De outra parte, não menos importante é a omissão, o descaso e a ineficiência das instituições 

CRIMINALIZAÇÃO DAS DROGAS

MARCO AURÉLIO SOUZA DA SILVA

públicas responsáveis pela fiscalização desses estabelecimentos, ao tolerarem as atrocidades cometidas diariamente.

As soluções correspondem sempre a medidas paliativas que visam acalmar a população amedrontada pelo discurso de pânico midiático, resumindo-se a ocupação militar, transferências de presos para outros presídios e promessas de investimentos, sem qualquer sinal de respeito aos direitos fundamentais. Aliás, deve-se frisar que as graves violações aos direitos fundamentais são perpetradas pelo próprio Estado, ao submeter seres humanos (que não perdem essa condição por estarem presos) a condições aviltantes que, muitas vezes, impõem aos encarcerados uma morte lenta e dolorosa.

Uma das razões de manutenção do caos carcerário se deve ao fato de que grande parte dos atores das mencionadas instituições também compartilha do senso comum acerca do paradigma etiológico da criminalidade, do eficientismo do sistema penal, da concepção de guerra às drogas, do controle social, do direito penal simbólico ${ }^{42}$ e da distante concretização de direitos fundamentais, especialmente do seu núcleo dignidade humana, projetando para suas manifestações (decisões, pareceres etc.) as mesmas percepções. ${ }^{43}$

42 O direito penal simbólico é uma expressão que designa que este ramo não cumpre suas funções declaradas, servindo mais como uma resposta simbólica à criminalidade, ao transmitir à sociedade a ideia de que a criação de novos tipos penais, o aumento de penas, o enrijecimento das regras de execução de penas e a redução de garantias processuais diminuirão a prática de delitos e trarão mais segurança.

${ }^{43}$ A propósito, Carvalho cita interessante pesquisa realizada pela Procuradoria Geral de Justiça em convênio com a Universidade Federal do Rio Grande do Sul acerca do perfil político-criminal dos membros do Ministério Público gaúcho: "Os procuradores e os Promotores de Justiça indagados sobre o motivo pelo qual escolheram a carreira do Ministério Público, em escala de prioridades, 57,7\% apontaram a crença na função social da instituição, sendo seguida, como segunda opção, além da própria função institucional (20,2\%), a atuação no combate à criminalidade, com 30,8\% das indicações, e a defesa dos direitos difusos e coletivos, com $20,2 \%$ de adesão. Confrontados diretamente sobre as opções político-criminais, $54,4 \%$ dos pesquisados identificaram-se com as políticas de tolerância zero, 26,9\% aderiram ao funcionalismo penal. Do total, $8,2 \%$ demonstraram-se influenciados pelo garantismo penal". Além disso, "na análise da legislação e do funcionamento do sistema penal, $83,8 \%$ aderiram à afirmação de que a legislação brasileira seria excessivamente branda, com demasiados benefícios aos réus e penas muito curtas, situação que dificultaria a contenção da criminalidade. Em relação à necessidade de ampliar a legislação para tutelar bens jurídicos ameaçados pelos novos riscos sociais, $82 \%$ manifestaram-se favoráveis à expansão do direito penal; e indagados sobre a possibilidade de esta expansão gerar a vulgarização do sistema penal, 62,8\% contrariaram a assertiva. Sobre a eficácia da Lei dos Crimes Hediondos em realizar as metas de prevenção geral e especial, 80,1\% concordaram com a afirmação". Citando outra pesquisa, realizada pela Associação dos Magistrados Brasileiros (AMB), também ficou evidente a tendência da magistratura em agir na potencialização do punitivismo e de obstaculizar a aplicação dos substitutivos como instrumentos alternativos à prisão. "Os Magistrados demonstraram-se totalmente favoráveis ou favoráveis à diminuição da idade penal (61\%), ao aumento do tempo de internação de menores em conflito com a Lei $(75,3 \%)$, ao aumento das hipóteses de internação de menores $(73,8 \%)$, ao aumento do tempo de cumprimento de pena para progressão de regime em crimes graves $(89,3 \%)$, ao aumento do tempo de cumprimento de pena para livramento condicional (81,5\%), à ampliação do sigilo das investigações em crimes graves (84,1\%), ao aumento da pena mínima para crimes de tráfico de drogas $(76,8 \%)$, à proibição da liberdade provisória, 
Diante da abordagem criminológica crítica, conforme já demonstrado (item 1), 0 inimigo no direito penal (traficante, usuário, entre outros), agora simbolizado pelo encarcerado, não é considerado (ou tem bastante reduzido o seu caráter de) titular de direitos fundamentais, como dignidade humana. Por estar vinculado ao controle social, o sistema carcerário permanece como a institucionalização da violação dos direitos fundamentais.

Não bastasse a gravidade da situação in loco, verifica-se a exclusão da questão carcerária nos debates das reformas penais. Segundo Olmo, apesar de os especialistas latinoamericanos considerarem a legislação penal, a polícia, o Poder Judiciário e o sistema penitenciário como partes integrantes do sistema penal, a maioria das reformas são concentradas em propor mudanças formais na legislação penal e no Poder Judiciário, com notória tendência de excluir a questão carcerária, mesmo sendo reconhecida como um dos setores mais deficientes do sistema penal. É o que a criminóloga chama de "silêncio carcerário". ${ }^{44}$

No entanto, apesar do discurso favorável à concretização dos direitos fundamentais e dos direitos humanos, da ampla quantidade de legislações nacionais e internacionais protetoras e da existência de recursos financeiros para investimento, a política pública carcerária ainda tem, como regra, o tratamento seletivo, desigual, degradante e desumano, violando sistematicamente direitos e garantias, não se vislumbrando interesse político em reverter tal situação.

\section{CONCLUSÃO}

Tendo em vista o objetivo inicialmente formulado e os apontamentos sobre o sistema penal, a criminologia, o encarceramento em massa impulsionado pela criminalização das drogas e os dados estatísticos da população carcerária, o presente estudo procurou evidenciar e conclui

com ou sem fiança, para crimes de tráfico de drogas $(74,5 \%)$, ao aumento de pena para casos de corrupção e improbidade $(95,6 \%)$, ao aumento do limite máximo de cumprimento de pena privativa de liberdade $(69,1 \%)$, à privatização do sistema carcerário $(49,4 \%)$, à ampliação das hipóteses de crimes hediondos $(50,9 \%)$. Em contraparte, e em certo grau de forma contraditória, manifestaram-se totalmente favoráveis ou favoráveis à ampliação da aplicação das penas alternativas $(64,9 \%)$ e ao caráter ressocializador da pena criminal $(86,4 \%)$ " (CARVALHO, Salo de. 0 papel dos atores do sistema penal na era do punitivismo $(0$ exemplo privilegiado da aplicação da pena). Série CriminologiaS: Discursos para a Academia. Rio de Janeiro: Lumen Juris, 2010, p. 101-102;104-105).

${ }_{44}$ OLMO, Rosa Del. ¿Por qué el actual silencio carcelario? Revista Violencia, sociedad y justicia en América Latina, Buenos Aires: CLACSO, set. 2001, p. 370-371. Disponível em: <http://biblioteca.clacso.edu.ar/ar/libros/violencia/violencia.html>. Acesso em: 29 set.2013. 
que não há como negar a existência de um controle social exercido pela política pública do sistema carcerário que institucionaliza a violação de direitos fundamentais, notadamente incidente de modo seletivo e preponderantemente sobre os indivíduos pertencentes às classes desfavorecidas ou vulneráveis.

O sistema penal enfrenta, há algum tempo, uma crise de legitimidade, na medida em que suas funções declaradas de combate à criminalidade, de ressocialização e reinserção social do condenado não mais se sustentam. O controle da criminalidade exercido pela repressão violenta e pela imposição da pena de prisão evidencia, a cada dia, a inutilidade do sistema penal alimentado pelo paradigma etiológico da Criminologia positivista, conforme denunciam os teóricos da Criminologia crítica.

O combate internacional às drogas, inclusive por meio de convenções, possibilitou a expansão do controle social punitivo exercido pelo sistema penal sob a roupagem de "guerra". A partir da intervenção do sistema penal com o proibicionismo criminalizador, as condutas relacionadas à produção e à comercialização dessas mercadorias foram transformadas, por meio da utilização de uma linguagem dramatizadora e demonizadora, no "tráfico de drogas" e no "crime organizado", ocultando a verdadeira face de intervenção do Estado penal sobre determinados indivíduos, sobre os quais recai a figura de "inimigo".

Observou-se que o controle social punitivo antidrogas ainda mantém uma diretriz de política pública criminal representada pelo fracasso (ou "sucesso") no encarceramento em massa, operado de modo seletivo, excludente e desigual. A análise crítica do sistema punitivo explica a ambiguidade do discurso dos fins sociais da pena de prisão, da retribuição, da prevenção geral e especial, sustentado pelos defensores da instituição carcerária e da Criminologia positivista, assim como desnuda a influência do poder do mercado e a redução do Estado social, que culminam com o controle social criminalizante dos excluídos e abandonados à própria sorte pelas instituições públicas, pela família, pela escola, pelo trabalho etc.

Não é demais relembrar que a violência observada na produção e no comércio das drogas ilícitas só ocorre devido à ilegalidade do mercado, fazendo nascer de modo paralelo também empresas ilegais, as quais se utilizam de armas (movimentando outro mercado ilegal) para enfrentar a repressão e a concorrência, porquanto impossibilitadas de buscar o Poder Judiciário para a solução dos conflitos.

A política de guerra às drogas foi e continua sendo propulsora do crescimento carcerário no Brasil, mas desmascarada pelos fins que promete, já que na verdade se trata essencialmente de persecução penal aos traficantes das calçadas e aos consumidores pobres. 
Isso porque o discurso de repressão ainda mantém a dicotomia social que diferencia usuário e traficante, estabelecendo prevenção ao consumo indevido e repressão ao tráfico. Na prática, como visto, trata-se da aplicação do paradigma médico aos jovens consumidores oriundos de classes sociais favorecidas (doentes que necessitam de serviços de saúde e reinserção social) e do paradigma penal aos jovens vendedores pertencentes às classes sociais desfavorecidas e vulneráveis (criminosos perigosos que devem ser combatidos e eliminados).

Os aportes teóricos criminológicos se amoldam às estatísticas, cujo cenário revela que no Brasil, entre os anos 2000 e 2010, o total de habitantes aumentou 12,48\%, enquanto que a população carcerária em geral aumentou 113,20\%. Tomado o índice de encarceramento para cada 100 mil habitantes, esse aumento foi de $89,55 \%$, evidenciando que a população carcerária, aproximadamente, dobrou em apenas 10 (dez) anos.

No mesmo período, os encarcerados por tráfico de drogas correspondiam a 9,09\% do total de reclusos em 2005, enquanto que em 2010 passaram a representar 21,45\% do total de reclusos, concluindo-se que a população encarcerada pela prática de tráfico de drogas mais do que dobrou, revelando uma política pública de incremento punitivo em nível nacional.

Confrontando-se os dados de encarceramento pela prática de delitos em geral com os especificamente relacionados às drogas, percebeu-se a barbárie de um sistema penal ampliado pelo controle das drogas, cujo crescimento do aprisionamento em massa mais que dobrou em 5 (cinco) anos (2005-2010).

De outra parte, os dados oficiais referentes ao grau de instrução da população carcerária no Brasil, entre 2005 e 2011, revelam a predominância absoluta de presos com ensino fundamental incompleto, característica de indivíduos pertencentes às classes desfavorecidas, quando confrontados com os de ensino superior completo. Do mesmo modo, dramática é a situação quando comparado o número absurdamente predominante de presos sem curso superior com os de nível universitário.

Também se infere do estudo que as condenações que resultaram nas estatísticas de encarceramento não representam necessariamente um ato de neutralidade e racionalidade científica dos julgadores, mas uma orientação ideologicamente seletiva (classista), cujo estereótipo é dado pelos marginalizados social e economicamente, conforme revela o grau de instrução dos apenados. Tal situação corrobora a ideia de que em sociedades marcadamente desiguais a política pública de controle social punitivo corresponde à administração de conflitos ideológicos. 
Ainda na questão das drogas, impulsionadora do encarceramento em massa, vale registrar que ela não é um problema criminal ou de segurança pública, mas um problema de saúde pública com repercussão na segurança pública. Sem a alternativa descriminalizante das drogas ilícitas, o massacre resultante do controle social punitivo por dentro da barbárie do sistema penal nessa "guerra" continuará se perpetuando em números estatísticos absurdos, sendo o cárcere o símbolo ilusório da segurança contra a criminalidade e o final da estação para os marginalizados social e economicamente.

Não se deve perder de vista que o encarceramento não serve para solucionar problemas sociais, pois ele mesmo já é um problema social, na medida em que não inibe a prática de condutas criminosas, não reduz a insegurança, não diminui a violência e não ressocializa ninguém, servindo apenas como instrumento de vingança, estigmatizador, destruidor de subjetividades, produtor e perpetuador da violência em seu espaço criminógeno.

Igualmente é preciso reconhecer não apenas a omissão, o descaso ou a ineficiência do Estado (Poder Executivo) em prestar política pública com respeito aos direitos fundamentais, consagrados constitucionalmente, mas também atribuir a situação caótica e degradante por que passa o sistema carcerário brasileiro ao significativo grau de conivência de instituições públicas (Judiciário, Ministério Público, Tribunal de Contas etc.) e da própria sociedade (que concebe o preso como um sujeito destituído de direitos) com essa situação.

Desse modo, a política pública carcerária brasileira segue institucionalizando a violação de direitos fundamentais, situação que somente será ultrapassada quando houver uma política voltada para a prevenção, articulando-se os campos da educação, saúde, moradia, saneamento básico, emprego, entre outras necessidades para o exercício de uma vida digna. $E$ isso não representa nada além do cumprimento dos direitos fundamentais em consonância com um Estado Constitucional e Democrático de Direito.

\section{REFERÊNCIAS}

ALEXY, Robert. Teoria dos direitos fundamentais. 2. ed., São Paulo: Malheiros Editores, 2011. ANDRADE, Vera Regina Pereira de. A ilusão de segurança jurídica: do controle da violência à violência do controle penal. 2. ed. Porto Alegre: Livraria/Editora do Advogado, 2003.

2003. Sistema penal máximo x cidadania mínima. Porto Alegre: Livraria do Advogado, 


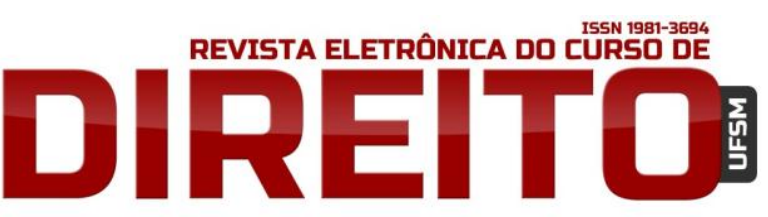

POLÍTICA PÚBLICA CARCERÁRCIA: UMA INSTITUCIONALIZADA VIOLAÇÃO DE DIREITOS FUNDAMENTAIS IMPULSIONADA PELA CRIMINALIZAÇÃO DAS DROGAS

MARCO AURÉLIO SOUZA DA SILVA

. Pelas mãos da criminologia: o controle penal para além da (des)ilusão. Rio de Janeiro: Revan, 2012.

BARATTA, Alessandro. Criminologia crítica e crítica do direito penal: introdução à sociologia do direito penal. 2. ed. Rio de Janeiro: Freitas Bastos, 1999.

- Direitos Humanos: entre a violência estrutural e a violência penal. Fascículos de Ciências Penais, Porto Alegre: Sérgio Fabris, ano 6, v. 6, n. 2, abr./jun. 1993.

. Introducción a una sociología de la droga: problemas y contradicciones del control penal de las drogodependencias. Disponível em:

<http://www.revistajuridicaonline.com/index.php?option=com_content\&task=view\&id=283\&lte mid=27>. Acesso em: 04 out. 2013.

BARROSO, Luís Roberto. O novo direito constitucional brasileiro: contribuições para a construção teórica e prática da jurisdição constitucional no Brasil. 2. reimp., Belo Horizonte: Fórum.

BATISTA, Vera Malaguti. O Tribunal de Drogas e o Tigre de Papel. Disponível em: <http://www.mundojuridico.adv.br>. Acesso em: 03 set. 2013.

BIANCHINI, Alice. Comentários ao art. 18. In: GOMES, Luiz Flávio et al. Lei de drogas comentada: Lei 11.343, de 23.08.2006. 4. ed. rev., atual. e ampl. São Paulo: Revista dos Tribunais, 2011.

BRASIL. Ministério da Justiça. Disponível em:

<http://portal.mj.gov.br/data/Pages/MJD574E9CEITEMIDC37B2AE94C6840068B1624D28407509CP TBRIE.htm>.

. Instituto Brasileiro de Geografia e Estatística. Disponível em:

<http://www.ibge.gov.br/home/estatistica/populacao/censo2010/tabelas_pdf/Brasil_tab_1_8.p $\mathrm{df}>$.

CARVALHO, Salo de. Substitutivos penais na era do grande encarceramento. In: ABRAMOVAY, Pedro Vieira; BATISTA, Vera Malaguti (Org.). Depois do grande encarceramento. Rio de Janeiro: Revan, 2010.

. O papel dos atores do sistema penal na era do punitivismo $(0$ exemplo privilegiado da aplicação da pena). Série CriminologiaS: Discursos para a Academia. Rio de Janeiro: Lumen Juris, 2010.

KARAM, Maria Lúcia. “Guerra às drogas” e criminalização da pobreza. In: ZILIO, Jacson; BOZZA, Fábio (Org.). Estudos críticos sobre o sistema penal: homenagem ao Professor Doutor Juarez Cirino dos Santos por seu $70^{\circ}$ aniversário. Curitiba: LedZe Editora, 2012, p. 692.

Proibições, riscos, danos e enganos: as drogas tornadas ilícitas. Col. Escritos sobre liberdade, Vol. 3. Rio de Janeiro: Lumen Juris, 2009. 


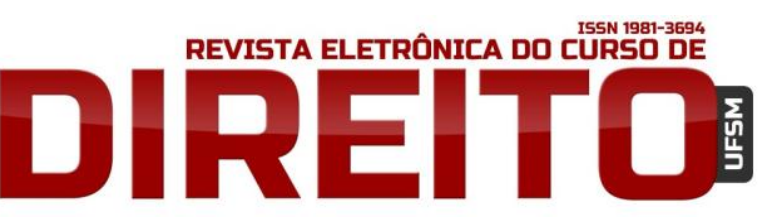

POLÍTICA PÚBLICA CARCERÁRCIA: UMA INSTITUCIONALIZADA VIOLAÇÃO DE DIREITOS FUNDAMENTAIS IMPULSIONADA PELA CRIMINALIZAÇÃO DAS DROGAS

MARCO AURÉLIO SOUZA DA SILVA

OLMO, Rosa Del. A face oculta da droga. Trad. Tereza Ottoni. Rio de Janeiro: Revan, 1990. - ¿Por qué el actual silencio carcelario? Revista Violencia, sociedad y justicia en

América Latina, Buenos Aires: CLACSO, set. 2001, p. 370-371. Disponível em:

<http://biblioteca.clacso.edu.ar/ar/libros/violencia/violencia.html>. Acesso em: 29 set.2013.

MENDES, Gilmar Ferreira; BRANCO, Paulo Gustavo Gonet. Curso de direito constitucional. 9. ed., rev. e atual., São Paulo: Saraiva, 2014.

SARLET, Ingo Wolfgang; MARINONI, Luiz Guilherme; MITIDIERO, Daniel. Curso de direito constitucional. 3. ed., rev., atual. e ampl. São Paulo: Revista dos Tribunais, 2014.

SARLET, Ingo Wolfgang. O direito fundamental à moradia na constituição: algumas anotações a respeito de seu contexto, conteúdo e possível eficácia. Revista Brasileira de Direito Público RBDP, Belo Horizonte, ano 1, n. 2, jul./set. 2003. Disponível em:

<http://bid.editoraforum.com.br/bid/PDI0006.aspx?pdiCntd=12524>. Acesso em: 18 fev. 2014.

Os direitos fundamentais sociais na Constituição de 1988. Revista Diálogo Jurídico,

Salvador, CAJ - Centro de Atualização Jurídica, v. 1, nº 1, 2001. Disponível em:

<http://www.direitopublico.com.br/pdf_seguro/revista-dialogo-juridico-01-2001-ingo-

sarlet.pdf>. Acesso em: 27 out.2013.

. Os direitos fundamentais sociais e os vinte anos da Constituição Federal de 1988: resistências e desafios à sua eficácia e efetividade. Revista do Instituto de Hermenêutica Jurídica - RIHJ. Belo Horizonte, Ano 1, nº 6, jan./dez. 2008.

SILVA, Marco Aurélio Souza da. O controle social punitivo antidrogas sob a perspectiva da Criminologia crítica: a construção da criminalidade do tráfico de drogas nas decisões judiciais. Rio de Janeiro: Lumen Juris, 2013.

SILVA, Marco Aurélio Souza da. O controle social punitivo antidrogas sob a perspectiva da criminologia crítica: a construção do traficante nas decisões judiciais em Santa Catarina. $372 \mathrm{f}$. Dissertação (Mestrado em Direito) - Programa de Pós-Graduação em Direito da Universidade Federal de Santa Catarina, Florianópolis, 2012.

ZAFFARONI, Eugenio Raúl; PIERANGELI, José Henrique. Manual de direito penal brasileiro: parte geral. 3. ed., rev. e atual. São Paulo: Revista dos Tribunais, 2001.

Recebido em: 26/02/2014 / Revisado em: 02/01/2015 / Aprovado em: 06/01/2015 